\title{
The Value of Vale: Negotiating the Progressivity of Service in a Market Restaurant
}

\author{
Rosina Márquez Reiter | ORCID: 0000-0001-6627-1813 \\ Professor of Spanish and Linguistics \\ School of Languages and Applied Linguistics \\ Faculty of Wellbeing, Education, and Language Studies \\ The Open University, Milton Keynes, United Kingdom \\ rosina.marquez-reiter@open.ac.uk
}

\author{
Marina Noelia Cantarutti | ORCID: 0000-0002-1490-3492 \\ Research Associate \\ School of Languages and Applied Linguistics \\ Faculty of Wellbeing, Education, and Language Studies \\ The Open University, Milton Keynes, United Kingdom \\ marina.cantarutti@open.ac.uk
}

\begin{abstract}
This paper examines the interactional functions of the Spanish conversational particle vale in the self-recorded service encounter interactions of a bidialectal restaurant server in an Ecuadorian restaurant in Madrid whose clientele are, by and large, of Ecuadorian descent.

The article details the sequential contexts in which vale is found as well as the grammatical and prosodic design of the turns where it is deployed, and contrasts its use with slots in the same dataset where alternatives were deployed instead. It also compares the findings with resonant descriptions from prior interactional studies of its English counterpart: okay, given the similarities in the interactional functions observed for vale.

Vale was identified as a standalone particle in third position during the ordering activity bearing rising or falling intonation to register the (in)completeness of the order and contingencies around it, and also as a turn-final agreement-eliciting tag with rising-falling intonation appended to announcements of imminent service to welcome clients or serve the dishes.
\end{abstract}




\section{Keywords}

progressivity - Ecuadorian and Peninsular Spanish - confirmation-eliciting tag standalone particle - multiactivity

\section{Introduction}

This article offers the first situated examination of the sequential contexts in which the Spanish conversational particle vale is found in service encounter interactions between a server and clients in a restaurant.

The functions of vale have been described in socio-pragmatic, discourse, and corpus studies (e.g., Cestero 2019; Cestero \& Moreno, 2008; Briz, 2008) with a greater focus on its role in the organisation of discourse and its use by different social groups. The closest English counterpart to vale - okay - has also received significant attention in pragmatics and conversation analysis with descriptions of its role in the organisation of units of discourse as well as for the development of social action. Our study compares some of these social action-relevant findings on okay to the uses of vale in the data, and contrasts them with prior discourse-oriented findings for vale.

The context examined in this paper is that of a restaurant where demands for the achievement of multiple activities (Haddington et al., 2014) by the server often occur simultaneously, and the progressivity (Stivers \& Robinson, 2006) of service into the next stages need to be managed. The sequential contexts where vale is found are here seen as constitutive of the unfolding of the actions the conversational particle helps to carry out and advance, rather than merely describing its placement to account for the relationship between utterances in a turn or the units of discourse that it brings together.

The analysis is based on the server's self-recorded audio interactions with clients and staff at the kitchen at an Ecuadorian market restaurant in Madrid. The restaurant setting that we concentrate on allows us to examine vale in a delimited communicative environment: that of a server simultaneously waiting multiple tables while coordinating orders with the kitchen. This, in turn, enables us to zero in on the functions of vale in the carrying out of a range of communicative actions: welcoming clients, taking orders, serving dishes.

The article maintains that, broadly speaking, vale orients to the seeking and achieving of intersubjective understanding in conversation and that this explains its relative high presence in the context of the market restaurant where orders are received, acknowledged, progressed or delayed. In this setting, vale was found to be tied to the coordination of multiple parallel service activities where the participants indicate, check and agree understanding 
of the various stages of the ordering and delivery processes and therefore manage the progressivity of service.

The paper contributes to the body of knowledge of vale by offering an examination of its functions in a context where the demands of multiple activities are to be met, with a focus on the action it supports. It contributes to contrastive pragmatics (e.g., Blum-Kulka et al., 1989; Aijmer, 2011) by presenting an analysis which draws on conversation analysis and insights from ethnography, two paradigms which have rarely been taken up in contrastive pragmatics or in pragmatics more generally. Conversation analysis allows us to analyse the patterns observed against the response they receive and treat the latter as evidence of the actions the participants orient to. Importantly, it requires us to compare the sequential contexts where vale could have been used but alternatives were utilised instead in order to understand the regularity of patterns observed; therefore, offering comparisons within the dataset.

In the following section, we provide a review of prior research on vale and English okay in the light of similar interactional functions observed for vale in the dataset. In Section 3, we introduce our data and methods. Section 4 presents the analysis of the data broken into the design and functions of the particle identified: vale as a (mostly standalone) conversational particle doing 'registering' in the ordering activity (4.1) and vale as an intersubjective tag in announcements of yet unfulfilled but imminent service (4.2), as well as the role of these functions in managing progressivity during simultaneous demands at the restaurant (4.2.1). Finally, in section 5 we present the conclusions of this study.

\section{Prior Studies of Vale}

One of the distinctive characteristics of Peninsular Spanish for speakers of other varieties of the language is the presence of the conversational particle vale. Vale is typically absent from other varieties of Spanish such as those spoken in the Americas. ${ }^{1}$ It is one of the notable features that distinguishes Spaniards from other speakers of Spanish and one of the first indexicals migrants in Spain acquire to negotiate meaning with Spaniards and others.

Vale derives from the verb "valer" ("be worth"), in the third person of the present tense, having undergone a process of grammaticalization from the semantic uses of "valer" as "be useful" or "be convenient" (Bosque \& Demonte, 1999: 4169).

1 In some varieties of Colombian and Venezuelan Spanish vale can be used for emphatic purposes in responsive positions to indicate agreement as in Mami, sí, vale ('Mum, yes, okay). 
Despite its perceived ubiquity in conversation, very few studies have examined the situated actions vale helps to achieve. For instance, socio-pragmatic research in Spanish largely inspired by variationist sociolinguistics, has generally focused on determining the frequency of use of some pre-determined functions of vale as a discourse marker according to social factors, such as age or gender (e.g., Martínez Caballero, 2020). In addition, pragmatic research based on large corpora of Spanish oral discourse, reported that it occurs in either turn-initial or responsive position, carrying out both text-organisational and interpersonal functions in 'colloquial discourse' (e.g., Briz 1998). To the best of our knowledge, there are no interactional pragmatic studies of vale that focus on the situated activities that it contributes to carry out in particular social settings, unlike for its English counterpart: okay (see section 2.1). In view of this, a contrast will be made between the identified uses of vale in the dataset of this study and those reported for okay.

In initial position, vale has been described as an opening discourse marker with a meta-discursive function indexing preparation for the speaker's upcoming utterance (Serrano Reyes, 2013). In this sense, it is used especially while prefacing extended turns at talk such as tellings or explanations, often accompanied with pues ("then").

In responsive position, vale has also been described as an organisational element. Serrano Reyes (2013, see also Briz, 1998, and Casalmiglia \& Tusón, 1999) reports its use as a conversation closing item, treated as a filler when speakers are moving towards producing their farewells.

As a responsive and receipt marker in interaction, vale has been treated as a closing discourse marker that speakers employ to express acceptance (Padilla García in Briz, Pons, and Portolés, 20o8), admission, or approval of what is inferred from a prior speaker's contribution (Zorraquino et al., 1999). Vale acknowledges the prior turn, while doing acceptance and expressing conformity after an offer, invitation, or proposal, or is used to display agreement with or confirmation of facts, events, objects described by the prior speaker (Cestero Mancera \& Moreno Fernández, 2008).

Functions related to disagreement have also been identified, where vale can act as a marker for concession before an objection or a request for a new explanation (Briz et al., 2008). It can also be deployed to preface a counterargument, or work as an "interrupting particle" indicating that the speaker does not want to continue along a given argumentative line (Serrano Reyes, 2013).

Moreover, vale has been found in interrogative form in turn-final position (i.e. "apéndice interrogativo") to request agreement and verification at the end of utterances (Briz et al., 2008; Cestero Mancera, 2019; Serrano Reyes, 2006). However, its position and use have until now been left largely undescribed. 


\subsection{English Okay}

As mentioned earlier, the interactional functions reported in this paper for vale resonate with many of those found for English okay. Prior pragmatic studies have focused on okay as a discourse marker. In other words, okay is seen as part of a group of "sequentially dependent elements that bracket units of talk" (Schiffrin, 1987:31), and manage forms of cohesion for larger stretches within discourse (e.g. see for discourse in pedagogic contexts, Edmonson, 1981; Edmonson \& House, 1981; House, 2013) or as intra-textual forms of interpretation cues across segments (i.e., pragmatic markers, Fraser, 1999; Aijmer \& Simon-Vandenbergen, 2006).

Conversational approaches are also concerned with the use of okay and its positioning within and across turns at talk. Unlike approaches that mainly focus on sequences of textual cohesion, interactional perspectives understand "sequence" in relation to the unfolding of action. Therefore, as a situated study of a particle in a particular context of interaction where actions and their progressivity are of paramount importance for service delivery and satisfaction, our findings and methods align more closely with conversation analytic studies of the English particle okay.

The uses of okay that have been described and are especially relevant to our present study of vale include: acknowledgment and confirmation (e.g., Schegloff, 1982) of the prior turn, indexing information receipt and displaying understanding in responsive second position (Condon, 2001; Condon \& Cech, 2003) and closing the sequence in second or third position (Schegloff, 2007). In addition, okay has been reported to index compliance and willingness after directives (Keevallik \& Weidner, 2021; Stivers, 2019).

Also, relevant to our situated study of vale is the use of okay as a transitional feature (Beach, 1993), especially in institutional encounters. Apart from its association with pre-closings (Sacks \& Schegloff, 1973), in institutional encounters okay may work as a pivot or a bridge (Merritt, 1978), closing prior sequences of action to which it acts as a response, while also projecting activity shifts, a "state of readiness" for next-positioned issues (Beach, 1993: 329, cfr. Gardner's "change-of-activity" tokens, 2001).

Finally, okay can also be employed as an invariant tag at the end of different kinds of actions. Beach (1993) notes that this is a way of soliciting and ensuring agreement or acceptance from a co-participant, particularly in a directive, which also happens in initiating informing actions (Couper-Kuhlen, 2021). In this respect, Holmes (1982) shows how tags in general create a slot for a response, often seeking to obtain agreement "to a proposition which the addressee may not like" (p. 6o). However, this tag-format of okay remains largely understudied. 
In the next sections we present the data and methods employed for this study (Section 3) and our own analytic findings around the deployment of vale and its alternatives in their situated use at the restaurant (Section 4) and how these compare to prior interactional studies of English okay.

\section{Methodology}

The data for this study were collected through participant ethnographic fieldwork conducted by the first author in April 2017 in a traditional indoor market in Madrid.

It is this restaurant where the first author helped waiting tables, making coffee, and washing dishes. The ethnography entailed notes from fieldwork, documentary evidence (e.g., local newspapers, flyers, etc.), interviews with the owners of stores, workers and clients, and the recording of service encounters. It is the latter that we focus on in this paper, introducing ethnographic fieldwork notes where appropriate to support our analysis.

The study is based on 2 hours of self-recorded data, adding up to 29 service encounters at the restaurant between Juan Pablo - the son of the restaurant's owner and its main server -, and clients. Juan Pablo (pseudonym) agreed to wear a lapel microphone during his shifts and the owner gave his consent for the data to be recorded. Notwithstanding this, Juan Pablo told the clients that the interactions were being recorded and sought their verbal consent.

An interactional pragmatics analysis (Márquez Reiter, 2009; Chi-Hé Elder \& Haugh, 2018) primarily informed by conversation analysis (e.g., Sacks,
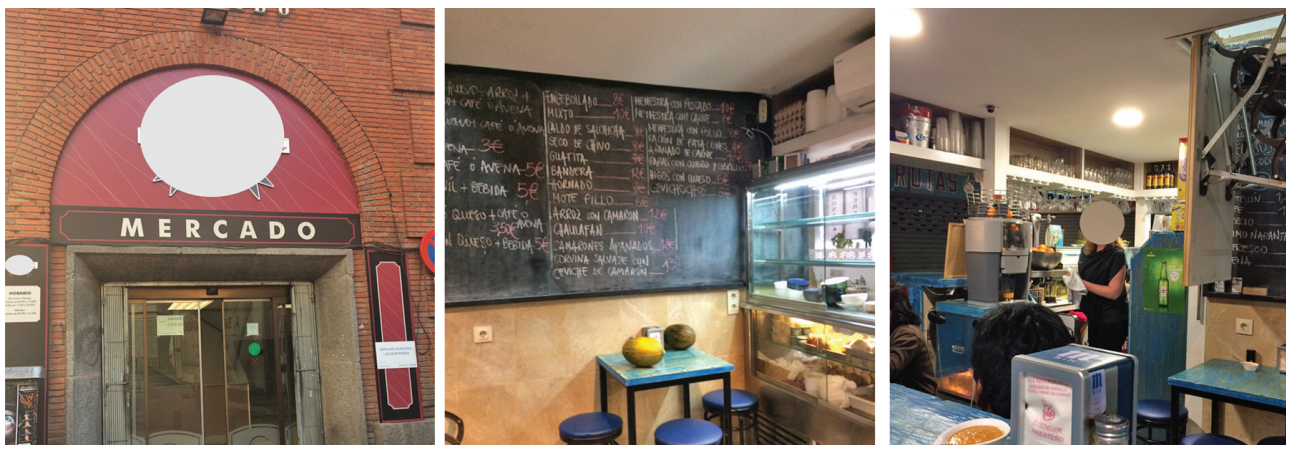

FIGURE 1 Left: Façade of the market - Centre: Juan Pablo's restaurant menu board - Right: the restaurant's kitchen, where one of the researchers carried out participant ethnography (reproduced with consent) 
Schegloff \& Jefferson, 1974) was carried out on the data in order to identify differences in the deployment of vale that contributed to the identification of given actions in particular sequential slots during the activities at the restaurant. This, in turn, allowed for the identification and contrast with alternatives to vale in comparable sequential contexts.

Each instance of vale was analysed in the light of its placement within the stages of the activity in progress. Vale occurred within actions carried out during three clear types of activity in the restaurant: welcoming clients, taking orders, or updating clients on the status of their order. Those turns not featuring vale where comparable actions were carried out in the same sequential position were also analysed for contrasting and validating purposes, thus making up a dataset divided into two groups, according to the wider activity in progress:

a) Vale as a (mostly standalone) particle and its alternative (repeats of the ordered item) in third position during the ordering process, realised with rising or falling intonation.

b) Vale as a tag or its absence during announcements of the immediacy of order fulfilment, realised with a contour phonologically associated to a rise-fall.

Prosodic analyses of the conversational particle were first conducted auditorily and impressionistically (Local \& Walker, 2005) then verified instrumentally on Praat (Boersma \& Weenink, 202O) and labelled according to Sp_ToBI conventions (Estebas-Vilaplana \& Prieto Vives, 2008).

As the interactions were self-recorded by the server who was engaged in several activities at once often addressing incoming or already-seated customers at a distance, it was not always possible to have access to customers' responses (see e.g., White, 2020 for a report on similar issues). The actions associated to vale were defined in terms of participant orientation whenever the voice of the client was hearable. In those sequences where the recording of the restaurant blurred the customers' responses, the following was considered:

a) the regularity of patterns in these turns relative to those where recipient responses were discernible coupled with the linguistic formulation of the turn,

b) the sequential position where vale was found,

c) knowledge gained from the ethnography (participant observation fieldwork notes) to supplement the interactional analysis in the light of the lack of other embodied information.

The transcription conventions comprise an adapted version of GAT-2 conventions (Selting et al., 2011, adapted by Ehmer et al., 2019, for Spanish; see Appendix), with interlinear glossing adapted from the Leipzig conventions 
(Comrie et al., 2008) for examples 7-11 only for those lines where the grammatical affordances of Spanish need to be appreciated.

\section{Analysis: Vale in Customer-Service Interactions at a Market Restaurant}

The restaurant's main server, Juan Pablo, moved from his native Ecuador to Madrid with his Ecuadorian parents at the age of 3 and is bidialectal. This is especially seen in the enclosure of the restaurant where traits of Ecuadorian Spanish are fused with his Madrileño dialect for goal-orientated purposes: to make the largely Ecuadorian-descent clientele feel at home.

Juan Pablo deployed vale when welcoming customers, taking orders, and delivering the food to the customers' tables. The design and action of vale have been found to be positionally-sensitive (Schegloff, 1996). Vale appears as a standalone particle in third position doing registering by indexing the completion or incompletion of the ordering activity, or as a tag-like particle eliciting a particular kind of confirmation/agreement from the customer at the end of turns where announcements by the server are made. The alternatives to vale in the same sequential position have also been considered, and a basic distribution of their occurrence appears on table 1 below.

TABLE 1 Instances of occurrence of vale and its alternatives in their relevant situated contexts

$\begin{array}{ll}\begin{array}{l}\text { Actions vale contributes to } \\ \text { carrying out }\end{array} & \begin{array}{l}\text { Position within the } \\ \text { turn or sequence }\end{array}\end{array}$

Registering the requested items during the ordering activity $(\mathrm{n}=39)$

In third position in the sequence

Seeking understanding and agreement Turn-final during announcements of immediacy of service fulfilment $(n=66)$ vale (generally standalone) ${ }^{\mathrm{a}}$

$(\mathrm{n}=19)$ repetition

$(\mathrm{n}=20)$

vale as tag

$(\mathrm{n}=24)$

zero (no tag)

$(\mathrm{n}=42)$

a As specified in 4.2.1, vale in third position (particularly when produced with rising intonation) may be followed by prosodically matched perfecto/no hay problema. 
As illustrated in table 1, vale plays an important role in the development of the service at the restaurant from the order-taking to the order delivery stages of the service alongside its alternatives.

\subsection{Vale as a Standalone Particle in the Ordering Sequence vs. Its Alternatives}

This first subgroup of uses of vale features vale as a mostly standalone particle in third position during ordering sequences. Vale is used to register the order, while orienting to progressivity by either displaying availability to advance the order onto the next stage, or by closing it altogether. In this sense, it is comparable to the "acceptance" uses described in the literature on vale (see section 2). It also resonates with the findings around okay as a bridge between activities or stages, but our collection shows that this use may also respond to particular circumstances.

The typical ordering sequence at this restaurant generally comes in cycles of repeated actions, with customers first requesting their starters, then the main course, and then the drinks, and each of these requests are acknowledged by Juan Pablo with vale or its alternatives (see section 4.1.1). Each of the components of the order (Lee, 2009) may be elicited in stages by the server, or customers may compress this extended sequential development by listing all the elements of the order at once. The ordered food and drink items are written down by Juan Pablo on a piece of paper.

Therefore, ordering activities are generally extended request sequences (Lee, 2009). The base (iterative) ordering sequence where vale can be found is as follows (actions between parentheses mark optional turns; labels from Schegloff, 2007):

$\mathrm{F}_{\mathrm{b} J \mathrm{P}}$ : verbal invitation to order

(Possible insert sequence:

Fins $\mathrm{C}$ : request of details about the menu

SinsJP: informing of details)

$\mathrm{s}_{\mathrm{b}} \mathrm{C}: \quad$ ordering of item(s)

SCT JP: acknowledgement/registering of the order $>$ vale or repetition

These situated uses of vale are described in detail below, together with a brief overview of alternative items in the same position for contrastive purposes. 
Excerpt (1) shows Juan Pablo confirming the customers' order (line 31) and closing the stage of the ongoing activity.

(1) $[01: 22]$

21 JP: ‘cuéntenme 'chicos;

Tell me guys

22 C1: a'guado'no?

Rice chicken soup, right?

23 C2: (qué [puedo)]

What can I-

24 JP: [agua ]do de 'pollo, $=$ o encebo'llado. $\mathbf{h}^{\circ}$

Rice chicken soup, or onion-and-rice soup

25 C1: (inaudible, addressing C2)

26 C2: (inaudible, addressing C1)

$27 \quad(0.8)$

28 C1: 'sí; = una de 'pollo? = y -una de:: (o.4)

Yes, a chicken one, and one with ...

29 'una de encebo'llado.

And an onion soup one

30

$31 \quad$ JP: $\quad<<$ cr $>$ vale: $>\mathbf{h}^{\circ}$

Vale $h^{\circ}$

Prior work on vale has acknowledged this closing use (e.g., Briz, 1998), however, the role of intonational design in orienting to differences in the development of the order has not received attention. Vale has been found to occur with either falling or rising intonation, but this differentiation is positionallysensitive within the wider ordering activity. Vale with falling intonation $\left(\mathrm{H}^{*} \mathrm{~L} \%\right)$ is found more frequently to close the ordering sequence altogether, 


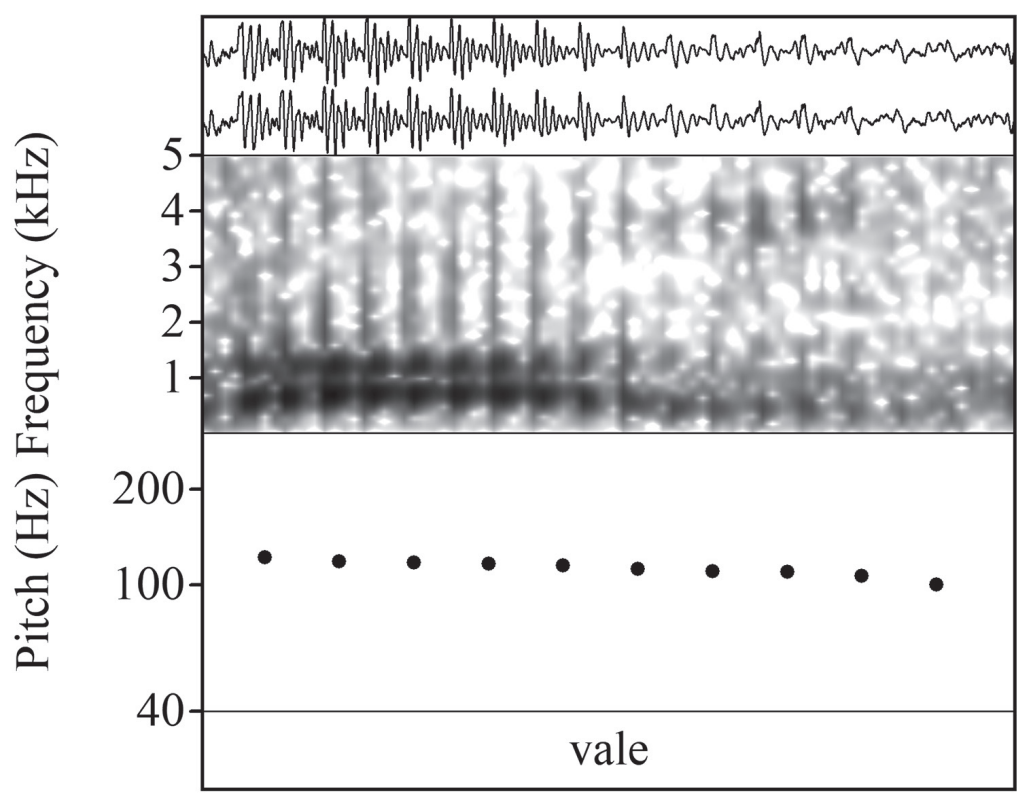

\section{Time (s)}

FIGURE 2 Waveform, spectrogram, and fo trace (in $\mathrm{Hz}, \log$ ) of sequence-closing vale in example 1 (line 31)

with the server registering and confirming understanding of the order thus far (e.g., Betz et al., 2021 for English okay). The falling tone starts over or around Juan Pablo's midline and finishes low in his range, and often with creaky voice, indexing the end of the larger ordering sequence.

Vale has also been found in its registering use with rising intonation, as excerpt (2) shows, but differs slightly in its positioning if the overall ordering activity is considered, and it also orients to other local contingencies in the order. This partly matches the uses of English rising-intonation okay in terms of indexing that there will be more talk from the prior speaker (e.g., Betz \& Depperman, 2021), that is, it functions as a continuer while still indexing registering of the order.

\section{(2) [oo:14]}

(Juan Pablo has run out of ink and interrupted the order-taking activity as his regular customers tease him about it. He now comes back to continue taking the order.) 
$49 \quad$ JP: $\quad \mathbf{a}^{\uparrow^{\top} \text { gua:doh }}{ }^{\circ}$ (.) se`gundo era menestra con pes`cado; = 'no? chicken rise soup, and for mains it was legume stew with fish, right?

50 C1: y:: $\mathrm{me}^{-}$nestra con ${ }^{-}$ca:rne (al `cerdo); And legume stew with pork meat

$5^{2} \quad \mathrm{C}_{2}:$ y el $\mathrm{m}$ y (el) menestra con pes'cado. And the l-and the legume stew with fish

54 C1: y para be ber = una (dos) de: man`zana. And to drink, an apple $(x)$

55 JP: 'vale?

Vale

56 C2: $\uparrow$ sabe que `yo voy a to-marme un: 'té. You know what? I'm going to have some tea

$57 \quad$ me ( $\downarrow$ voy a poner $)$ un 'té. I'm gonna get myself some tea

$5^{8}$ JP: 'vale, = per'fecto, Vale, perfect

The prosodic shape of the rising intonation $\left(\mathrm{L}^{*} \mathrm{H} \%\right.$, see fig. 3 ) in these vale tokens (lines 55 and $5^{8}$ ) presents different degrees of excursion, generally starting below the speaker's midline, and rising towards the mid or higher portions in the speaker's range.

This phonological difference between rising and falling intonation vale has been found to index different levels of completion of the ordering activity. Vale with rising intonation as in excerpt (2) works in a pivotal or bridging way (Merritt 1978, Beach 1993), that is, retrospectively and prospectively. It registers the just-ordered items (lines $5^{\mathrm{O}-55}$ ) and projects that there is more to the order that is currently missing, either an item or taking the order from some other customer in the same party, as shown in line 56 in (2) above. 


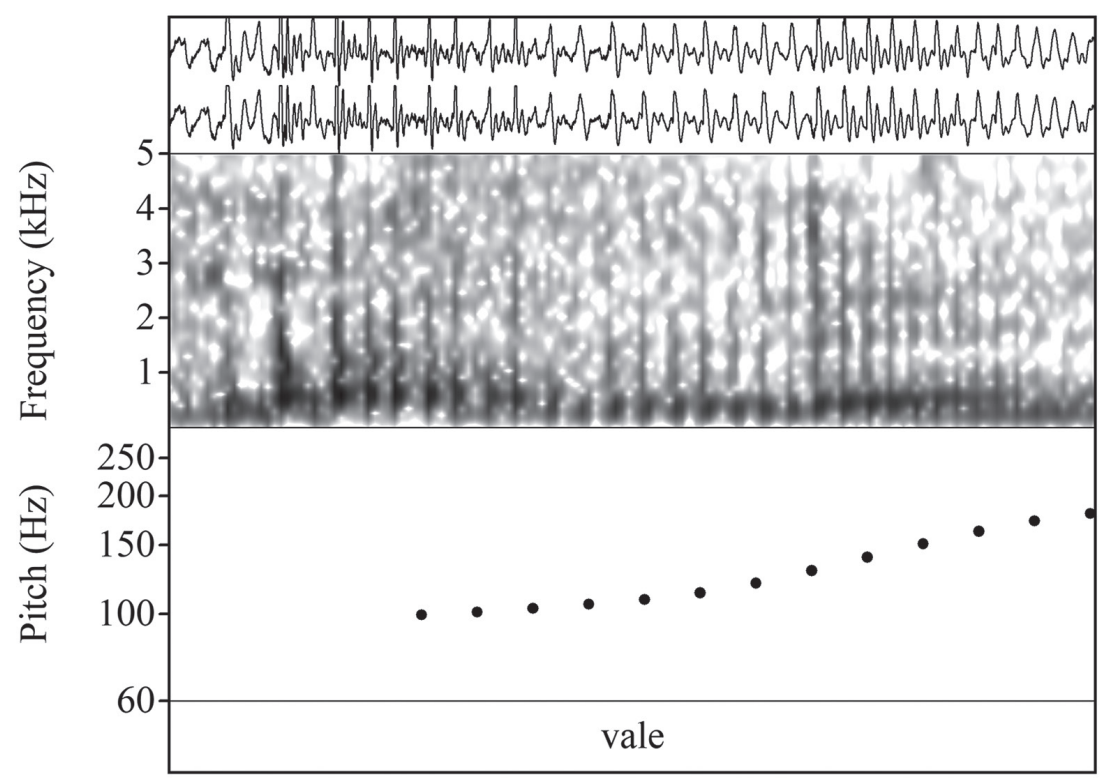

Time (s)

FIGURE 3 Close-up of waveform, spectrogram, and fo trace (in $\mathrm{Hz}, \log$ ) of vale in example 2 (line 55)

The orientation to the non-finality of the ordering process is also evidenced in the customers' behaviour, who may themselves advance on to the next steps in the order or produce order (re)completions.

Vale with rising intonation may be followed with a latched and prosodicallymatched "perfecto" (perfect) or "no hay problema" (no problem) as in in excerpts $(2-3)$, where vale also displays an orientation to exceptional circumstances: the customer has made a request that may be "out of the ordinary" for the restaurant and as such it warrants an account (Raevaara, 2011). This is illustrated in example (3) below, where the customer orients to the fact that sharing a meal and ordering a meal to takeaway are not usual practices at this restaurant. The observations conducted during fieldwork indicate that customers typically order the menu to eat at the restaurant. The set meals are generally accompanied by black coffee, beer or a fizzy drink. This "out-of-the-ordinariness" is also illustrated in example (2) above, where the customer frames the request in a way that indexes it as problematic or unusual in some way, e.g., the "sabe qué?" (line $5^{6}$ ) when he orders tea to accompany a full meal. In this respect, these uses of vale are reminiscent of the "discrepancy 
of expectation" (Betz \& Depperman, 2021: 89) described for circumstances where rising-intonation okay is deployed in English and German but unlike these uses, our instances do not generate situations that require solving by the prior speaker. Rather, they are part of requests to be granted by the waiter but which may engender accounts and elaborations, as seen above.

In excerpt (3) below, the relevant next action of ordering that was projected after "ustedes?" in line 27 is not fulfilled straightaway. The customer provides a long preface that delays her ordering activity indexing her re-direction of action away from the conditional relevance set by the waiter's prior turn. The customer's response strings together a sequence of "mira" ("look", line 28; see Sidnell, 2007), followed by a mitigation (line 29, "si no te importa"), and an account (line 30 "es que como que no tengo mucho hambre") before announcing their intention of sharing a meal.

(3) $[01: 28]$

27 JP: us $^{\prime}$ tedes? $\mathbf{h h}^{\circ}$

Andyou?

28 C: vale. 'mira.

Vale. Look.

$29 \quad$ (a mí si no te im 'porta;)

(For me if you don't mind)

30 es que como que no 'tengo mucha 'hambre;

It's just that as I'm not very hungry

$31 \quad$ vamos a compartir un mènú. = we are going to share a meal

$32=\mathrm{y}$ así pro $\downarrow$ bamos.

And so we try it.

33 JP: son dos `platos: (.) en $\downarrow$ 'tonce[s. $=\uparrow{ }^{\wedge \prime}$ va $]$ le?

It's two courses, then, vale?

$34 \mathrm{C}:$

[’sí. ]

Yes 
36 JP: 'vale:? = <<all > sin pro'blema?>

Vale, no worries.

After a clarification of what the menu consists of (two courses) and an understanding check (line 33) with "entonces" preceding vale in turn-final position, Juan Pablo confirms the acceptance of what was presented as an announcement of something extraordinary. The customer proceeds to announce the ordering of a second menu to take away (line 34), followed by vale in initial position with continuing intonation and a subsequent vale as a tag, this time with rising intonation. The server's response confirms the request with rising-intonation vale in turn-initial position followed by "sin problema" (line 36). With this, he relieves the aura of trouble from the request and emphasises its acceptance. These uses of vale resonate with English okay when acquiescing to proposals or requests that may require some disruption (Rauniomaa et al., 2012; Stivers, 2019).

The rising-intonation vale could thus be understood as a composite (Rossi, 2018). It registers the order as incomplete as well as indicating agreement and granting of what looks like a request for exceptional circumstances.

\subsubsection{Alternatives to Vale for Doing Registering Work}

The comparison of positionally-equivalent slots where vale is found to be doing registering work reveals as an alternative practice the repetition of ordered items, which also does confirmation and acknowledgement in response to a different type of interactional contingency in the order.

These repeats in third position are designed with either falling, rising, or level intonation with elongated sounds that accompany the embodied process of the writing down of the order. Repetitions may introduce volunteered confirmations (Persson, 2015). They are deployed to guarantee the successful progression of the order for both the server and the customers' sake, ensuring intersubjective understanding by leaving on record what was heard, preventing repair initiations later (Kuroshima, 2010). In the data, repetitions often appear contiguous to decisions made by the customer after food or drink alternatives have been listed by the waiter. This sets them apart from falling-intonation vale where the straightforwardly ordered items are taken as registered and understood. Excerpt (4) below shows how the waiter repeats the customer's decision (line 72) after presenting the options available (line 70). 
(4) $[00: 14]$

69 C: (para mí eh) dame una cer'veza; = dos cer'vezas.

For me eh give me a beer $=$ two beers

$70 \quad$ JP: $\quad$-tercio: $=$ bote $^{-} l$ li:n(g) $\mathbf{h}^{\circ}$

Medium bottle, a bottle ...

71 C: ‘tercio.

A medium bottle

$72 \quad \mathrm{JP}: \quad \downarrow$ tercio.

A medium bottle

Overall, repetitions are seen to occupy the slot where vale could have been used, particularly after customers have picked their order from a list just provided by the server; reflecting a contingency around the ordering process itself.

\subsection{Vale as an Intersubjective Tag}

Our next sub-collection of productions by the server features a different use and design of vale: it is formatted as an invariant tag comparable in form to that described in Briz et al. (2008) for soliciting agreement and verification, and to the initial observations for English okay by Beach (1993, see section 2.1). It is post-positioned after an announcement orienting to a delay in the forthcoming service, either on initially approaching the customers to take the food order, or on its delivery. Contrary to the prior mostly standalone vale tokens that registered the prior activity and projected the request of next components of the ordering activity in third position, this tag-like vale deals with progressivity in terms of unfulfilled order-taking or food delivery activities. It is found appended to updates on orders presented as being due (excerpt 7 ), or announcements of the forthcoming availability of the waiter to serve the waiting customers (excerpt 8), both of which act as promises of imminent service.

Given that the data consist of audio recordings and the sequences included in this section have been produced at a distance from the customers - as shown by Juan Pablo's upward shifts in loudness -, there are limited records of any non-verbal summons or customer greetings. However, the server's verbal behaviour (coupled with the information from the timestamped ethnographic notes) confirm that customers are seen to be waiting for service, either the delivery of food, or to sit down and/or request their order ("hovering", Laurier et al., 2001). Evidence for these service problems mainly also lie in the waiter 
addressing customers with formulations that explicitly acknowledge a delay in the release of the order from the kitchen, for example:

(5) $[00: 31]$

JP: te es $\uparrow$ tán haciendo espe`rar; = 'no?

They are making you wait, right?

(6) $[01: 44]$

JP: < <rall > 'chicas lo 'vuestro? = está en pro`ceso $={ }^{\wedge}$ vale, $>$

Girls, yours is in progress, vale?

[lo:: ] $](0.8)$

The:: $(0.8)$

Cl2: $[(\mathbf{x x x x x x})]$

((inaudible 6 syllables))

JP: lo 'rico, = 'siempre se hace espe'rar.

What is delicious always makes you wait for it

Therefore, the announcements that vale is appended to are responsive to some evidence of unfulfilled service and orient to the multiple demands that Juan Pablo as a waiter is attending to. The typical positioning of vale as an intersubjective tag at these points in the sequence is as follows:

Fpre C: (summons or hovering)

Spre/Fb JP: Announcement of imminent service (+ proposal) + vale?

Sb C: (acknowledgement token)

However, these short sequences are embedded within other sequences of ongoing activities and they open new participation frameworks (Goffman, 1981), as they occur during multiactivity, with Juan Pablo suspending the service to the current customers or the activity in the kitchen to address the newcomers or the customers waiting, and then continues the focused activity (see examples 9-11). 


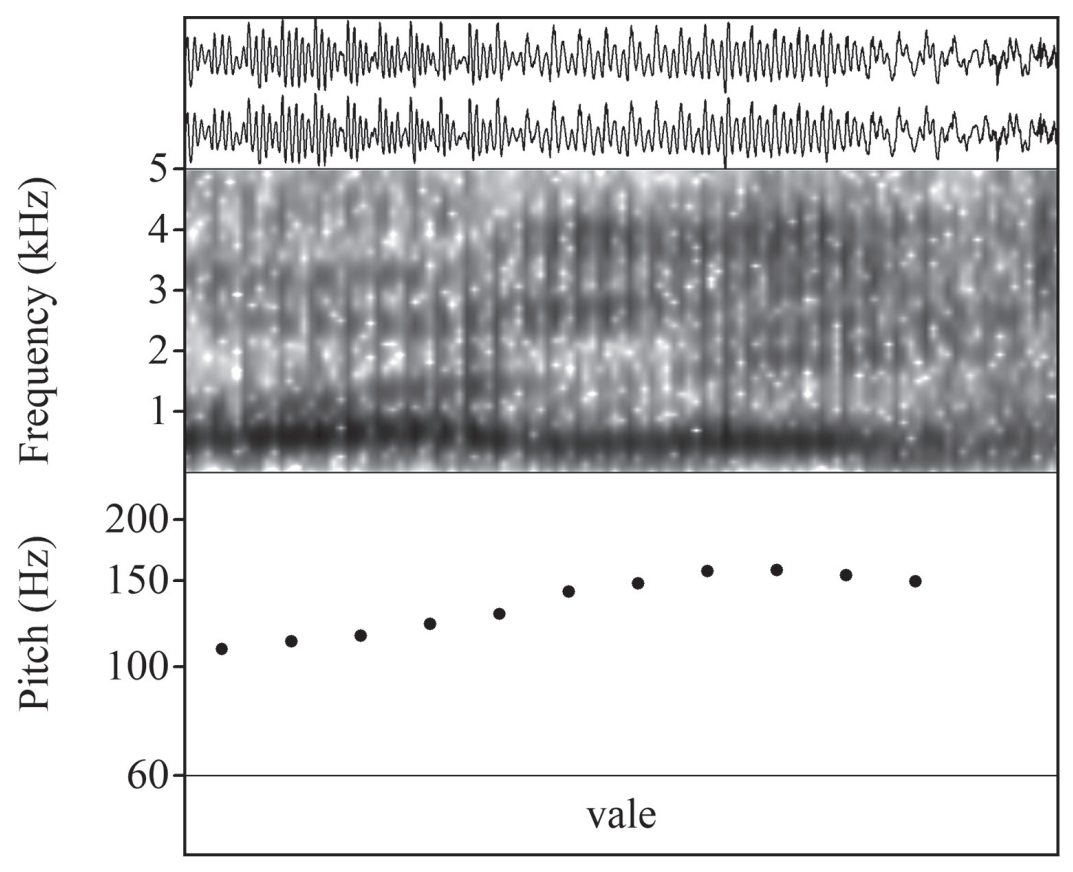

\section{Time (s)}

FIGURE 4 Waveform, spectrogram, and fo trace (in $\mathrm{Hz} \log$ ) of line 1 in excerpt 7 below

The prosodic design of tag-like vale also differs from the prior uses described. It is here produced with what phonologically could be associated with a rise-fall tone $\left(L^{*}+H L \%\right.$ or $L^{*}+H$ M\%) as is often found in invariant tags in Spanish (Cestero Mancera, 2019), even though some cases exhibit phonetic variation in either the width of excursion or alignment of the fo peak, and some even feature levels of compression (Estebas-Vilaplana \& Prieto, 2010).

As a tag (cfr. with okay in section 2.1), vale creates a slot for a response (Holmes, 1982) that may or may not be filled, and whose lack of (verbal) answer is not treated as accountable in the data. Excerpts $7-8$ below show instances where the announcements are hearably responded to, revealing the potential for recipient confirmation that tag-like vale opens up:

(7) [oo:39]

o1 JP: (37.0) ((whistling)) 
O2 $\quad<<\mathrm{p}>$ ya te `sale lo `tuyo = ^vale; $>$ imminently DAT.2SG go.out-PRS.3SG ACC.M.SG yours vale yours is coming out shortly

o3 C: perfecto.

Perfect

(8) $[01: 24]$

o1 $\quad(5.2)(($ cutlery noise $))$

o2 JP: ya te $<<\mathrm{f}>\uparrow$ hago la co'manda. $>$

Already ACC.2SG do-PRS.1SG DEF-F.SG order

I'll take your order shortly/imminently

O3 (1.1) ((cutlery noise))

O4 JP: te lo 'llevo por a`quí:, =

DAT.2SG ACC-M.3SG take-PRS.1SG for here

I'm taking it to you over here

O5 JP: ya te: a'tiendo. = ^vale;

Already ACC.2SG assist-PRS.2SG vale

I'll be with you in a sec, vale?

o6 C: $\uparrow$ 'vale.

Vale

07

((cutlery noise $))$

Whether responded to or not, the turns to which these vale particles are appended are responsive or "seconds" as the server's announcements occur in response to the service that has not been fulfilled in a timely manner. Therefore, the announcements are an orientation to the service contract, a recognition of unfulfilled service and a form of involvement with the waiting client through the creation of a slot for the confirmation of understanding from the customer, with whom the service is contracted. Thus, the opportunity for a response is open but it is not pursued if not forthcoming (see Couper-Kuhlen, 2021, for English okay as a tag). 


\subsubsection{Vale as a Tag and the Management of Progressivity and Multiactivity}

It is clear from the hearable evidence in prior excerpts and the ethnographic notes that these announcements that may or may not feature an appended vale tag happen during multiactivity (Haddington et al., 2014): they are done while the waiter is engaged in another activity and cannot fully attend to incoming customers, or is not at that moment directly dealing with the client waiting for their order to be delivered. The responsive opportunity that vale creates is then consequentially relevant to this management of multiactivity and the temporary change of participation frameworks.

Vale in these turns projects a transition-relevance place that contributes to the hearability of closure of the turn addressed to these parties who are not part of the main activity that the waiter was primarily managing. Vale has a role in managing these boundaries and the progressivity (Stivers \& Robinson, 2006) towards the next stages of the service, while indexing the immediacy of upcoming service, formulated as a promise.

Our data show that vale is very frequently deployed during the initial stages of the service encounter, where the customer is to be welcomed and a oneto-one relationship is to be established (Harjunpää et al., 2018), but the server in this case is not yet available to do so and is thus, more greatly accountable for this. The presence of vale creates a dialogic opportunity with the customer until their focused interaction can happen thus advancing the service, while also marking a boundary between simultaneous activities. After having managed the accountable absence of the service being due with the other customers and ending that turn with vale, the server returns to the main activity at hand. Excerpt (9) below shows the server's management of multiactivity, shifting between an ordering activity (lines 8-10) to instructing the newcomers (lines 11-12), back to the interrupted ordering activity (lines 13-14):

(9) [oo:13:oo]

o8

JP: $\quad<<\mathrm{f}>\uparrow$ ya $\wedge$ saben $(\mathrm{g}) ;>$

Have you decided already?

o9

10 C: yo un a-gua:[do:]

A chicken rice soup for me

$11 \quad$ JP: $\quad<<\mathrm{f}>\left[{ }^{\prime} \operatorname{chi}\right] \operatorname{co}^{\circ} \mathrm{h}=$ menú del $^{\prime}$ día, $=$ a la mitad de la pi'zarra;= 
Guy-PL menu of the day to DEF-F.SG half of DEF-F.SG board Guys, today's specials appear in the middle of the blackboard

12

14

13 C: e:h el aguado de 'pollo, = y el ence 'bollado.

$\mathrm{JP}:$ = y a la de'recha, plato a la 'carta. ^'vale? $>{ }^{\circ} \mathrm{h}$

and to DEF.F.SG right dish to DEF-F.SG carte and to the right, a la carte menu, vale? e:h the rice chicken soup $=$ and the onion-and-rice soup

(1.2) ((ruffling of paper noise))

Juan Pablo's use of Ecuadorian forms is also traceable here, as the verb conjugation indicates that customers are referred to as "ustedes" and not "vosotros", whereas the newcomers are addressed with Peninsular Spanish "chicos", and a vale tag.

Moreover, the presence of vale seems to go beyond the marking of this boundary to allow for an elicitation of agreement, of a deal that confirms consent with the commitment that the announcement entails. In these cases, there is a re-actualisation of the timeline, with the customer being asked to wait for a bit longer, or to be engaged in an autonomous activity while the server can offer the expected/promised service (see examples 9-11). The presence of vale creates a slot for customer confirmation of this being a new "deal": the acceptance of a promise of forthcoming service at the earliest opportunity.

4.2.2 Zero-Tag Alternatives to Vale as Tag

These issues of due-ness and imminence related to the unfulfilled "contractual" aspects of the service of one-to-one attention and speed are part of the very formulation of the turns where vale as a tag is found and of comparable turns that are seen to carry out the same action but may not bearvale. The announcements of immediate service are frequently formulated with the aspectual adverbial ya (see excerpts (10) and (11) below, with close English translations being imminently, shortly, but with a meaning akin to both already and almost there). The adverb ya frames (Delbecque, 2006) different time planes concurrently: it orients to a past time, in the present, through the viewpoint of an activity that is ongoing and imminent, with reference to the future. Delbecque \& Maldonado (2011) highlight the use of ya to identify "an imminent event as if it were 'already' materializing in the here-and-now" (p. 74). Ya has also been described as an element that involves a promise in its formulation (Zorraquino \& Portolés, 1999, and see Couper-Kuhlen, 2021 for okay as a tag after a promise). 
However, a comparison between these announcements of immediacy with $y a$ produced with or without vale as tag bear a connection with the display of the server's accountability and agency. Vale is found more often appended to announcements on actions that the server bears greater accountability and agency for: the taking of the order and the welcoming of the clients, over those fulfilled by other staff: preparation of the dish and its release from the kitchen. The examples below (10-11) also show the orientation to due-ness and the announcement of the imminent delivery or assistance, with vale in the announcements on the activities the waiter is personally accountable for providing (e.g. "ya te alzo los platos" excerpt 10) against those without it that pertain to the kitchen (e.g., "ya sale", excerpt 11).

(10) [o1:18]

O1 JP: las be $\uparrow$ bidas de esta 'gente. $=$ por fa $\downarrow$ 'vor.

These people's drinks, please

$\mathrm{O} 2 \quad(\mathbf{2 . 6})$

o3 JP: < <all, $\mathrm{f}>$ por ^qué no se me a`comoda= why NEG REFL DAT.1SG get.settled-PRS.2SG(usted)

Why don't you get settled?

O4 JP: = ya te aa:: > alzo los `platos yo = "vale?

Imminently DAT.2SG pick.up-PRS.1SG DEF-M.PL plate-S ISG vale? I'll pick up the plates in no time, vale?

O5 aco \'módate; mientras `tanto.

Get.settled-IMP.2SG-REFL meanwhile

Get settled in the meantime

(11) [oo:35]

o1 JP: <<all $>$ ya le paso $>$ pi $^{-}$cante cu^biertos;

imminently DAT.2SG pass-PRS.1SG chilly cutlery

I'll bring chilly sauce cutlery

$\mathrm{O} 2$

$\mathrm{y}$ toda $(\mathrm{s})$ las de 'ley = ^vale.

and all DEF-F.PL of law vale

and all the lawful things shortly vale 
o4 JP: <<all > ya `sale ña ñito > = ya `sale: hhh $^{\circ}$

imminently go.out-PRS.3SG chum-DIM.M.SG imminently go.out-PRS.3SG

It's coming, chum, it's coming $h h^{\circ}$

What is more, examples (10) and (11) above show Juan Pablo's orientation to the delay in the clients' order and his accountability as evidenced by the use of personal and impersonal constructions preceded by the clitic te, indexical of Peninsular Spanish (vs. the Ecuadorian le): "ya te alzo los platos yo" (10, line 4), "ya le paso picante" (11, line 1). The use of the impersonal in (11) below as well as other instances of "ya sale"/ "it's coming" (16 cases from the 42 tag-less announcements in the collection) allows him to disclaim agency (Enfield \& Kockelman, 2017) for the delay in the service. Yet, at the same time, it enables him to convey accountability for his role as a waiter: he is being attentive.

These turns also reveal features of Ecuadorian Spanish (e.g., "ñañito" in excerpt 11) that are not accompanied by vale (cfr. example 7 where the verb "salir" is preceded by the clitic "te" and is vale-appended), versus those featuring second person forms of address with "tú" most typical of the Peninsular variety as indicated by the verbs with vale tags appended to them.

It can be surmised that the turns in which these vale-appended announcements occur carry out a number of simultaneous actions that open a slot for acknowledgement/acceptance by the customer, where the server indexes that the service is forthcoming while indicating (albeit implicitly) whether it is in the server's hands to deliver the aspects of the service that are due at the expected moment, and at the same time, requesting that the customer do something themselves (wait further, help themselves to a seat, take a look at the menu). Vale creates an opportunity for dialogic involvement, intersubjective understanding and confirmation of the new terms of service, while also managing the boundaries and progress of other ongoing activities in the restaurant setting.

\section{5}

\section{Conclusion}

This paper has attested to the versatility and polyfunctionality of vale in a context where multiple activity demands are placed on the server. We have seen how vale can carry out the action of confirming understanding and registering a request during the ordering activity. It simultaneously indexes, through 
a falling tone, the closing of the ordering process or through a rising tone, the projection of a missing component in the ordering process, and the acknowledgement of a request that has been formulated as possibly exceptional by the customer but has been granted without problems.

Vale was also found in (mostly ya-prefaced) announcements that are responsive to an acknowledged delay in the service that the server may be accountable for not having yet provided. Vale is more widely present in the server's announcement of imminent attention during a period of current unavailability to welcome and help the customers settle, activities he is accountable for doing timely. These turns happen during multiactivity, with vale marking a boundary between the server's momentary attention to the newcomers and his return to the ongoing activity with other customers. Vale was normally not found when announcing imminent releases of the order from the kitchen.

Vale as a tag works akin to saying "deal?" or "agreed?" while checking intersubjective understanding. Vale creates a responsive slot where the customer could confirm their agreement to the updated "terms of service" - but whose answer is not pursued if not forthcoming -, with a new timeline that foregrounds the immediacy of the imminent but yet missing service in a way that acknowledges the delay and issues a promise. The presence of the aspectual adverbial $y a$ in conjunction with vale, and the object clitics te/le contribute then not only to this acknowledgment of the delay, but also offer this personalisation and registering of each individual order which is required or expected in restaurant service.

Despite some similarities with English okay in terms of the actions, position and design, our description of vale is embedded within the context of multiple activities taking place and evidences relevant alternatives to the particle in this particular context. Moreover, the actions associated to rising-intonation vale and vale as a tag expand the set of actions described for both Spanish vale and English okay.

Notwithstanding the specificity of the setting examined and the limitations of audio-recorded data to fully capture embodied action, the functions of vale identified with their intonational design are likely to be relevant to other interactional contexts. We have shown that the acknowledging, registering and agreement-requesting functions of vale hereby described, their prosodic design and sequential positioning, and the social-indexical meanings are activity-based. Activities involving such actions are likely to emerge in other communicative arenas where vale is deployed by participants. What is more, studies based on data that can capture the full embodied and material 
activity could contribute further to this characterisation of vale by describing the gestural and gaze patterns accompanying its deployment, providing further evidence for the role of vale in the management of evident multiactivity as shown here. Ethnographic knowledge supplemented the analysis in those cases when restaurant's noise blurred the client's responses, and ethnographic contributions also contributed to an exploration of vale and its alternatives in the waiter's reading of the clients.

Although our study was not originally conceived of as contrastive as traditionally understood, contrast was made by way of comparing alternatives to vale within the dataset to add validity to the regularity of patterns observed. This was made possible by adopting methods of conversation analysis which enable data-endogenous comparisons and contrasts in addition to comparing results, where appropriate, with reference to interactional studies of its English counterpart (okay) and extant research on vale.

\section{Appendix: Transcription Conventions (Adapted from GAT-2 Selting et al., 2010; Ehmer et al., 2019)}

For readability, accented syllables initiating relevant pitch movements are marked with pitch accent marks and not with CAPITALS.

[] overlap and simultaneous talk

$=$ latching

$\circ \mathrm{h} / \mathrm{h}^{\circ} \quad$ in-/outbreaths

(.) micro pause, estimated, up to o.2 sec. duration appr.

(o.5) measured pause (to tenth of a second)

$\left(\mathrm{h}^{\circ}\right) \quad$ interspersed laughter particles

(xx) unintelligible syllables

: lengthening

Final pitch movements

? rising to high

, rising to mid

- level (not marked in final position)

; falling to mid

. falling to low

Notation of pitch accent movements

falling

rising 
- level

$\wedge$ rising-falling

$\checkmark$ falling-rising

$\uparrow$ pitch upstep

$\downarrow$ pitch downstep

Loudness and tempo changes, with scope

$<<\mathrm{l} / \mathrm{h}>\mathrm{xx}>$ Lower/higher pitch register

$<<\mathrm{f} / \mathrm{p}>\mathrm{xx}>\mathrm{loud} / \mathrm{soft}$

$<<$ all $>\mathrm{xx}>$ allegro, fast

Changes in voice quality and articulatory settings, with scope

$<<$ cr $>\mathrm{xx}>$ creaky

$<<$ other features $>\mathrm{xx}>$ other observations

\section{Acknowledgments}

We are grateful to Dr. Salvador Pons for the comments on an early version of this article, and to Dr. Lluisa Astruc for her feedback and guidance on our ToBI annotations for this article.

The data collection was supported by a Santander mobility research grant (2017) in the context of a Spanish Ministerio de Ciencia e Innovación grant on "Linguistic Modes: an ethnographic approach to new speakers in Europe" (FF12O15-67232-C3-1-P).

\section{Declaration}

We declare that this manuscript is original and that is not being considered for publication elsewhere. We have no conflicts of interest to disclose.

\section{References}

Aijmer, K. (Ed.) (2011). Contrastive Pragmatics. John Benjamins: Amsterdam.

Aijmer, K., \& Simon-Vandenbergen, A. M. (2006). Pragmatic Markers in Contrast. Elsevier: Amsterdam.

Beach, W. A. (1993). Transitional regularities for casual "Okay" usages. J. Pragmatics, 19, $325^{-}-35^{2}$. 
Beach, W. A. (1995). Conversation analysis: "Okay" as a clue for understanding consequentiality. In Sigman, S. (Ed.). The Consequentiality of Communication (pp. 129-170). Routledge: London.

Betz, E., \& Deppermann, A. (2O21). OKAY in responding and claiming understanding. In Betz, E., Deppermann, A., Mondada, L., \& Sorjonen, M.-L. (Eds). OKAY across Languages: Toward a comparative approach to its use in talk-in-interaction (pp. 55-92). John Benjamins Publishing Company: Amsterdam.

Betz, E., Deppermann, A., Mondada, L., \& Sorjonen, M.-L. (2021). OKAY across Languages: Toward a comparative approach to its use in talk-in-interaction. John Benjamins Publishing Company: Amsterdam.

Blum-Kulka, S., House, J., \& Kasper, G. (1989). Cross-cultural pragmatics: Requests and apologies. Ablex Publishing Corporation: Norwood, NJ.

Boersma, P., \& Weenink, D. (2020). Praat:Doing Phonetics by Computer. 2019.[Computer program]. Version 6.1.o9.

Bosque, I., \& Demonte, V. (Eds.). (1999). Gramática descriptiva de la lengua española. Espasa.

Briz, A. (1998). El español coloquial. Esbozo de pragmagramática. Ariel, Barcelona.

Briz, A., Pons, S., \& Portolés, J. (2008). Diccionario de Partículas Discursivas del Español. http://www.dpde.es/\#/.

Casalmiglia Blancafort, H., \& Tusón Valls, A. (1999). Las cosas del decir. Manual de análisis del discurso. Barcelona, Ariel.

Cestero Mancera, Ana María. (2019). Apéndices interrogativos de control de contacto: estudio sociolingüístico. Cuadernos de Lingüística de El Colegio de México, 6(1), el11. 18 de febrero de 2020. https://doi.org/10.24201/clecm.v6i1.111.

Cestero Mancera, A. M., \& Moreno Fernández, F. (2008). Usos y funciones de 'vale y venga!' en el habla de Madrid. Boletín de Lingüística, 20(29), 65-84.

Comrie, B., Haspelmath, M., \& Bickel, B. (2008). The Leipzig Glossing Rules: Conventions for interlinear morpheme-by-morpheme glosses. Department of Linguistics of the Max Planck Institute for Evolutionary Anthropology \& the Department of Linguistics of the University of Leipzig. Retrieved from: https://www.eva.mpg.de/ lingua/pdf/Glossing-Rules.pdf.

Condon, S. L. (2001). Discourse ok revisited: Default organization in verbal interaction. J. Pragmatics, 33(4), 491-513.

Condon, S. L., \& Cech, C. G. (2003). Ok, next one: Discourse markers demonstrate understanding of common ground. 8th Annual Convention of the International Pragmatics Association. Unpublished manuscript.

Couper-Kuhlen, E. (2021). The prosody and phonetics of OKAY in American English. In Betz, E., Deppermann, A., Mondada, L., \& Sorjonen, M.-L. (Eds). OKAY across languages: Toward a comparative approach to its use in talk-in-interaction (pp.131-174). John Benjamins: Amsterdam. 
Delbecque, N. (2006). 'Ya': Aclaración cognitiva de su uso y función. Revista Española de Lingüística, 36(1), 43-72.

Delbecque, N., \& Maldonado, R. (2011). Spanish ya. A conceptual pragmatic anchor. J. Pragmatics, 43(1), 73-98.

Edmondson, W. (1981). Spoken Discourse: A Model for Analysis. Longman.

Edmondson, W., \& House, J. (1981). Let's Talk, and Talk about it: A Pedagogic Interactional Grammar of English. Urban \& Schwarzenberg.

Ehmer, O., Satti, I., Martinez, A., \& Pfaender, S. (2019). Un sistema para transcribir el habla en la interacción: GAT 2. 20, 64-114.

Elder, Chi-Hé, \& Haugh, M. (2018). The interactional achievement of speaker meaning: Toward a formal account of conversational inference. Intercultural Pragmatics, 15(5): 593-625.

Enfield, N. J., \& Kockelman, P. (2017). Elements of agency. In Enfield, N. \& Kockelman, P. (Eds) Distributed Agency (pp. 3-8). Oxford University Press.

Estebas-Vilaplana, E., \& Prieto Vives, P. (2008). La notación prosódica del español: Una revisión del Sp-ToBI. Estudios de Fonética Experimental, 17, 264-283.

Estebas-Vilaplana, E., \& Prieto Vives, P. (2010). Castilian Spanish intonation. In Prieto, P., \& Roseano, P. (2010). Transcription of intonation of the Spanish language $(17,48)$. München: Lincom Europa.

Fraser, B. (1999). What are discourse markers? Journal of Pragmatics, 31(7), 931-952.

Gaines, P. (2011). The Multifunctionality of Discourse Operator Okay: Evidence from a police interview. Journal of Pragmatics, 43(14), 3291-3315.

Gardner, R. (2001). When Listeners Talk: Response Tokens and Listener Stance. J. Benjamins Publishing.

Goffman, E. (1981). Forms of Talk. University of Pennsylvania Press.

Gumperz, J. (1964). Linguistic and social interaction in two communities. American Anthropologist, 66(6), 137-153.

Haddington, P., Keisanen, T., Mondada, L., \& Nevile, M. (2014). Towards multiactivity as a social and interactional phenomenon. In Haddington, P., Keisanen, T., Mondada, L., \& Nevile, M. (Eds.): Multiactivity in Social Interaction: Beyond Multitasking (pp. 3-32). John Benjamins Publishing.

Harjunpää, K., Mondada, L., \& Svinhufvud, K. (2018). The Coordinated Entry into Service Encounters in Food Shops: Managing Interactional Space, Availability, and Service During Openings. Research on Language and Social Interaction, 51(3), 271-291.

Holmes, J. (1982). The functions of question tags. English Language Research Journal, $3,40-65$.

House, J. (2013). Developing pragmatic competence in English as a lingua franca: Using discourse markers to express (inter)subjectivity and connectivity. Journal of Pragmatics 59, 57-67. 
Keevallik, L., \& Weidner, M. (2021). Chapter 11. OKAY projecting embodied compliance to directives. In Betz, E., Deppermann, A., Mondada, L., \& Sorjonen, M.-L. (Eds.), OKAY across Languages: Toward a comparative approach to its use in talkin-interaction (pp. 337-362). John Benjamins Publishing Company.

Kuroshima, S. (2010). Another look at the service encounter: Progressivity, intersubjectivity, and trust in a Japanese sushi restaurant.Journal of Pragmatics, 42(3), 856-869.

Laurier, E., Whyte, A., \& Buckner, K. (2001). An ethnography of a neighborhood café: Informality, table arrangements and background noise. Journal of Mundane Behavior, 2(2). http://eprints.gla.ac.uk/23/.

Lee, S. -H. (2009). Extended requesting: Interaction and collaboration in the production and specification of requests. Journal of Pragmatics, 41(6), 1248-1271.

Local, J., \& Walker, G. (2005). Methodological imperatives for investigating the phonetic organization and phonological structures of spontaneous speech. Phonetica, $62(2-4), 120-130$.

Márquez Reiter, R. (2009). How to get rid of a telemarketing agent: Face-work strategies in a Spanish intercultural service call. In Bargiela-Chiappini, F. and Haugh, M. (eds) Face, Communication and Social Interaction. London: Equinox, pp. 55-77.

Martínez Caballero, I. (2020): Estudio sociopragmático de las partículas discursivas vale y ivenga! para su aplicación en la Enseñanza de Español como Lengua Extranjera $(E L E)$. E-eleando. ELE en Red. Serie de Monografías y materiales para la enseñanza de ELE, 15. http://www3.uah.es/e-eleando.

Merritt, M. (1978). On the use of "OK" in service encounters. Southwest Educational Development Laboratory.

Ostermann, A. C., \& Harjunpää, K. (2O21). OKAY in health helpline calls in Brazilian Portuguese: managing alignment and progressivity. In Betz, E., Deppermann, A., Mondada, L., \& Sorjonen, M. -L. (Eds). OKAY across Languages: Toward a comparative approach to its use in talk-in-interaction (pp. 269-300). John Benjamins Publishing Company: Amsterdam.

Padilla García, X. (2008). “Vale”. In: Briz, A., Pons, S., \& Portolés, J. (2008). Diccionario de Partículas Discursivas del Español. http://www.dpde.es/\#/.

Persson, R. (2015). Registering and repair-initiating repeats in French talk-ininteraction. Discourse Studies, $17(5), 583-608$.

Pillet-Shore, D. (2003). Doing 'Okay': On the Multiple Metrics of an Assessment. Research on Language and Social Interaction, $36(3), 285^{-319}$.

Raevaara, L. (2011). Accounts at convenience stores: Doing dispreference and small talk. Journal of Pragmatics, 43(2), 556-571.

Rauniomaa, M., \& Keisanen, T. (2012). Two multimodal formats for responding to requests. Journal of Pragmatics, 44(6), 829-842.

Richardson, E. (2014). The order of ordering: analysing customer-bartender service encounters in public bars. Doctoral dissertation, Loughborough University. https:// 
repository.lboro.ac.uk/articles/The_order_of_ordering_analysing_customer-bartender _service_encounters_in_public_bars/9480368.

Rossi, G. (2018). Composite Social Actions: The Case of Factual Declaratives in Everyday Interaction. Research on Language and Social Interaction, 51 (4), 379-397.

Sacks, H., \& Schegloff, E. A. (1973). Opening up closings. Semiotica, 8(4), 289-327.

Sacks, H., Schegloff, E. A., \& Jefferson, G. (1974). The simplest systematics for the organization of turn-taking for conversation. Language, 50(4), 696-735.

Schegloff, E. A. (1982). Discourse as an interactional achievement: Some uses of 'uh huh' and other things that come between sentences. In D. Tannen (Ed.), Analyzing Discourse: Text and Talk. Georgetown University Press.

Schegloff, E. A. (1996). Turn organization: One intersection of grammar and interaction. In Interaction and Grammar (pp. 52-133). Cambridge University Press.

Schegloff, E. A. (2007). Sequence Organization in Interaction: A Primer in Conversation Analysis, Volume 1. Cambridge University Press.

Schiffrin, D. (1987). Discourse Markers. Cambridge: Cambridge University Press.

Schleef, E. (2008). The "lecturer's ok" revisited: Changing discourse conventions and the influence of academic division. American Speech, 83(1), 62-84.

Selting, M., Auer, P., Barth-Weingarten, P., Bergmann, J., Bergmann, P., Birkner, K., Couper-Kuhlen, E., Deppermann, A., Gilles, P., Günthner, S., Hartung, M., Kern, F., Mertzlufft, C., Meyer, C., Morek, M., Oberzaucher, F., Peters, J., Quasthoff, U., Schütte, Stukenbrock, A., and Uhmann, S. (2011). A system for transcribing talk-ininteraction: GAT 2. Gesprächsforschung: Online-Zeitschrift Zur Verbalen Interaktion, $12,1-51$.

Serrano, M. J. (2006). Gramática del discurso. Ediciones AKAL.

Serrano Reyes, P. (2013). Análisis socio-pragmático del marcador conversacional vale como iniciador de intervención. Estudios Interlingüísticos, 1, 135-147.

Sidnell, J. (2007). 'Look'-prefaced turns in first and second position: Launching, interceding and redirecting action. Discourse Studies, 9(3), 387-408.

Stivers, T. (2019). How We Manage Social Relationships Through Answers to Questions: The Case of Interjections. Discourse Processes, 56(3), 191-209.

Stivers, T., \& Robinson, J. (2006). A Preference for Progressivity in Interaction. Language In Society, 35(3), 367-392.

White, A. E. C. (2020). Authority and camaraderie: The delivery of directives amongst the ice floes. Language in Society, 49(2), 207-230.

Zorraquino, M., \& Portolés, J. (1999). Los marcadores del discurso. In Bosque, I. \& Demonte, V. (1999). Gramática Descriptiva de La Lengua Española, 3, 4051-4213. 